\title{
SISTEM PENDUKUNG KEPUTUSAN PEMILIHAN PESERTA KAPAL PEMUDA NUSANTARA DENGAN MENGGUNAKAN METODE WEIGHTED PRODUCT (WP)
}

\author{
Noprin Pakaya ${ }^{1}$ dan Amiruddin ${ }^{2}$ \\ 1noprin.pakaya92@gmail.com, ${ }^{2}$ amier.76@gmail.com \\ 1,2Universitas Ichsan Gorontalo
}

\begin{abstract}
Abstrak
Pemilihan peserta Kapal Pemuda Nusantara merupakan program Kementerian Pemuda dan Olahraga yang mana proses pemilihannya diberikan hak kepada setiap Provinsi untuk memilih pemuda terbaik di daerah masing-masing, sebanyak 5 orang yang terdiri dari (2 putra, 2 putri) dan 1 orang calon peserta (1 putra atau 1 putri). Proses penyeleksian pemilihan peserta Kapal Pemuda Nusantaramasih terdapat masalah yang dihadapi, diantaranyasulitnya memilih peserta yang tepat dan berkualitaskarena banyaknya peserta yang ikut seleksidan banyaknya kriteria yang digunakan serta masih adanya unsur penilaian secara subyektif sehingga membutuhkan ketelitian dalam pengambilan keputusan. Tujuan dari penelitian ini adalah membangun sebuah aplikasi sistem pendukung keputusan dengan menggunakan metodeWeighted Product.Berdasarkan hasil penelitian aplikasi yang sudah dibangun dapat membantu pihak pengambil keputusan dalam menentukan alternatif terbaik peserta Kapal Pemuda Nusantarauntuk kategori Laki-Laki dengan nilai tertinggi 0,22327 dan untuk kategori Perempuan dengan nilai tertinggi 0,21771dan proses pemilihannya menjadi lebih obyektif.
\end{abstract}

Kata Kunci: Kapal Pemuda Nusantara, Weighted Product.

\section{Pendahuluan}

Kapal Pemuda Nusantara merupakan salah satu program pelayaran dengan mengundang pemuda-pemudi perwakilan dari setiap provinsi yang memenuhi syarat yang bertujuan untuk, memunculkan, membangkitkan motivasi pemuda untuk mau ke laut serta menstimuli tumbuhnya wirausaha pemuda di bidang kelautan. Selain itu untuk membentuk jaring kerja nasional pemuda, memperkuat dan meningkatkan jiwa dan semangat NKRI sekaligus memberdayakan pemuda sebagai kader bangsa. Para pemuda dari seluruh nusantara ini akan diajak berlayar untuk mengenal potensi bahari yang dimiliki Indonesia, mempelajarinya, memberikan rekomendasi terhadap masalah yang terdapat di lapangan, dan pada akhirnya kelak sebagai purna kegiatan dapat mengaplikasikan ilmu yang didapat selama program di daerahnya masing-masing dalam upaya mengoptimalkan pemberdayaan potensi bahari[1].

Penyeleksiancalon peserta Kapal Pemuda Nusantara di Provinsi Gorontalo dimulai dari tahun 2010 hingga sekarang, rata-rata jumlah peserta setiap tahunnya \pm 60 orang sedangkan yang akan diterima hanya 5 orang yang terdiri dari (2 putra 2 putri) dan 1 orang calon peserta (1 putra atau 1 putri) yang akan menjadi peserta Kapal Pemuda Nusantara berdasarkan kriteria ataupun persyaratan calon peserta yang telah ditentukan oleh pihak Dikbudpora Provinsi Gorontalo. Adapun kriteria yang digunakan adalah usia, pendidikan terakhir, jumlah prestasi dibidang organisasi kependudukan, tinggi badan, berat badan, daya tahan renang, jumlah kesenian/budaya daerah yang dikuasai, dan nilai proposal tentang potensi kebaharian daerah asal peserta[1]. Untuk mendapatkan atau memilih peserta Kapal Pemuda Nusantara yang berkualitas berdasarkan kriteria yang sudah ditentukan merupakan kendala tersediri yang dihadapi oleh pihak Dikbudpora, karena banyaknya peserta yang mendaftardan banyaknya kriteria yang digunakan serta masih adanya unsur penilaian secara subyektif sehingga membutuhkan ketelitian dalam proses pengolahan datanya.

Berdasarkanmasalah diatas, maka perlu dibuatkan suatu Sistem Pendukung Keputusan (SPK), Sistem Pendukung Keputusan merupakan bagian dari sistem informasi berbasis komputer termasuk sistem berbasis pengetahuan atau manajemen pengetahuan yang dipakai untuk mendukung pengambilan keputusan, dapat juga dikatan sebgai sistem yang mengelola data menjadi informasi untuk mengambil keputusan,Sistem Pendukung Keputusan (SPK) ini sangat dibutuhkan oleh tim seleksi karena mempunyai kemampuan untuk memecahkan masalah yang multiobjective dan multicriteria yang akan menyeleksi alternatif terbaik sehingga dengan sistem ini akan memberikan 
kemudahan bagi pihak Dikbudpora Provinsi Gorontalo dalam proses penyeleksian calon peserta Kapal Pemuda Nusantara (KPN) yang lebih obyektif.

Aplikasi Sistem Pendukung Keputusan yang akan dibuat menggunakan Metode Weighted product (WP),karena metode ini merupakan salah satu metode penyelesaian yang ditawarkan untuk menyelesaikan masalah Multiple Attribute Decision Making (MADM)[2], dan Metode ini telah dibuktikan oleh beberapa penelitian sebelumnya, diantaranyapenelitian yang dilakukan oleh Lestari [3] dengan judul penerapan metode Weighted Product Model untuk seleksi calon karyawan, dimana hasil yang didapatkan dengan menggunakan metode ini cukup baik dan lebih tepat. Penelitian yang dilakukan oleh Arsyad [4] didapatkan hasil pemilihan BEM STMIK Banjarbaru lebih obyektif, dan penelitian yang dilakukan oleh Niswatin [5] dengan hasil penelitian yaitu proses seleksi mahasiswa baru di Universitas Nusantara PGRI Kediri lebih mudah, cepat dan tepat. Dari hal tersebut membuktikan bahwa metode Weighted Product (WP) dapat diterapkan pada kasus ini untuk dapat memberikan solusi terbaik dalam pemilihan Peserta Kapal Pemuda Nusantara (KPN).

\section{Metode}

\subsection{Sistem Pendukung Keputusan}

Konsep Sistem Pendukung Keputusan (SPK) atau Decision Support Systems (DSS) pertama kali diungkapkan pada awal tahun 1970-an oleh Michael S. Scott Morton dengan istilah Management Decision Systems

Morton, et al mendefinisikan DSS sebagai "Sistem Berbasis Komputer Interaktif, yang membantu para pengambil keputusan untuk menggunakan data dan berbagai model untuk memecahkan masalah-masalah yang tidak terstruktur". [6]

Menurut Alter, DSS merupakan sistem informasi interaktif yang menyediakan informasi, pemodelan dan pemanipulasian data. Sistem digunakan untuk membantu pengambilan keputusan dalam situasi yang semi terstruktur dan situasi yang tidak terstruktur, dimana tak seorang pun tahu secara pasti bagaimana keputusan seharusnya dibuat. [7]

DSS (Decision Support Systems) biasanya dibangun untuk mendukung solusi atas suatu masalah atau untuk mengevaluasi suatu peluang. DSS yang seperti itu disebut aplikasi DSS. Aplikasi DSS digunakan dalam pengambilan keputusan. Aplikasi DSS menggunakan CBIS (Computer Based Information Systems) yang fleksibel, interaktif dan dapat diadaptasi yang dikembangkan untuk mendukung solusi atas masalah manajemen spesifik yang tidak terstruktur. [7]

Pada dasarnya SPK ini merupakan pengembangan lebih lanjut dari Sistem Informasi Manajemen Terkomputerisasi (Computerized Manajement Information Systems), yang dirancang sedemikian rupa sehingga bersifat interaktif dengan pemakainya. Sifat interaktif ini dimaksudkan untuk memudahkan integrasi antara berbagai komponen dalam proses pengambilan keputusan, seperti prosedur, kebijakan, teknik analisis, serta pengalaman dan wawasan manajerial guna membentuk suatu kerangka keputusan yang bersifat fleksibel [7].

\subsection{Komponen-Komponen Sistem Pendukung Keputusan}

Menurut Turban [6], Sistem Pendukung Keputusan terdiri dari 4 subsistem yaitu :

1. Manajemen Data, meliputi basis data yang berisi data-data yang relevan dengan keadaan dan dikelola oleh perangkat lunak yang disebut Database Management System (DBMS).

2. Manajemen Model berupa sebauh paket perangkat lunak yang berisi model-model finansial, statistik, management science, atau model kuantitatif yang menyediakan kemampuan analisa dan perangkat lunak manajemen yang sesuai.

3. Subsistem Dialog atau komunikasi, merupakan subsistem yang dipakai oleh user untuk berkomunikasi dan memberi perintah (menyediakan user interface).

4. Manajemen Knowledge yang mendukung subsistem lain atau berlaku sebagai komponen yang berdiri sendiri.

\subsection{Konsep Dasar Multiple Attribute Decision Making (MADM)}

MADM adalah salah satu metode yang digunakan untuk mencari alternatif optimal dari sejumlah alternatif dengan kriteria-kriteria tertentu. Inti dari Multiple Attribute Decision Making (MADM)adalah menentukan nilai bobot untuk setiap atribut/kriteria, yang kemudian dilanjutkan dengan proses perankingan yang akan menyeleksi alternatif yang sudah diberikan. Pada dasarnya, ada 3 (tiga) pendekatan untuk mencari nilai bobot atribut, yaitu pendekatan subyektif, pendekatan obyektif dan pendekatan integrasi antara subyektif \& obyektif. Masing-masing pendekatan memiliki kelebihan dan kelemahan. Pada pendekatan subyektif, nilai bobot ditentukan berdasarkan 
subyektifitas dari para pengambil keputusan, sehingga beberapa faktor dalam proses perankingan alternatif bisa ditentukan secara bebas. Sedangkan pada pendekatan obyektif, nilai bobot dihitung secara matematis sehingga mengabaikan subyektifitas dari pengambil keputusan [2].

Beberapa metode yang dapat digunakan untuk menyelesaikan masalah MADM antara lain [2] :

a. Simple Additive Weighting Method (SAW)

b. Weighted Product (WP)

c. Electre

d. Technique for Order Preference by Similarity to Ideal Solution (TOPSIS)

e. Analytic Hierarchy Process (AHP)

\subsection{Metode Weighted Product (WP)}

Metode WP merupakan salah satu metode penyelesaian yang ditawarkan untuk menyelesaikan masalah Multi Attribute DecisionMaking (MADM). Metode WP mirip dengan Metode Weighted Sum (WS), hanya saja metode WP terdapat perkalian dalam perhitungan matematikanya. Metode WP juga disebut analisis berdimensi karena struktur matematikanya menghilangkan satuan ukuran.

Menurut Yoon dalam Kusumadewi, Metode WP menggunakan perkalian untuk menghubungkan rating atribut, dimana rating setiap atribut harus dipangkatkan dulu dengan bobot atribut yang bersangkutan. Proses ini sama halnya dengan proses normalisasi.

Preferensi untuk alternatif diberikan sebagai berikut [2] :

$$
\mathrm{S}_{\mathrm{i}}=\prod_{j=1}^{n} X_{i j}{ }^{w j} \quad \text {;dengan } \mathrm{i}=1,2, \ldots, \mathrm{m} .
$$

Dimana

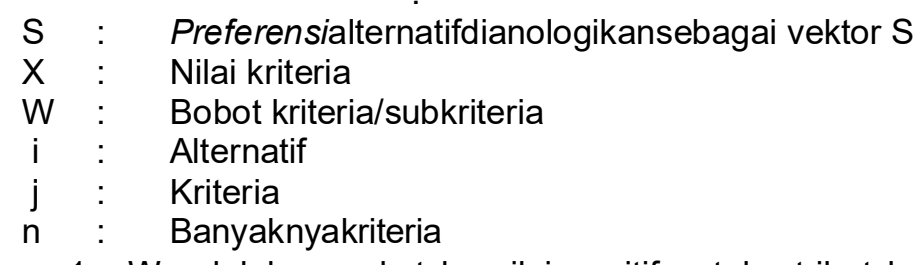

Dimana $\sum \mathrm{w}_{\mathrm{j}}=1 . \mathrm{W}_{\mathrm{j}}$ adalah pangkat bernilai positif untuk atribut keuntungan, dan bernilai negatif untuk atribut biaya.

Preferensi relatife dari setiap alternatif, diberikan sebagai :

$$
V_{i}=\frac{\prod_{j=1}^{n} X_{i j}{ }^{w j}}{\prod_{j=1}^{n}\left(X_{j}^{*}\right)}
$$

Dimana :

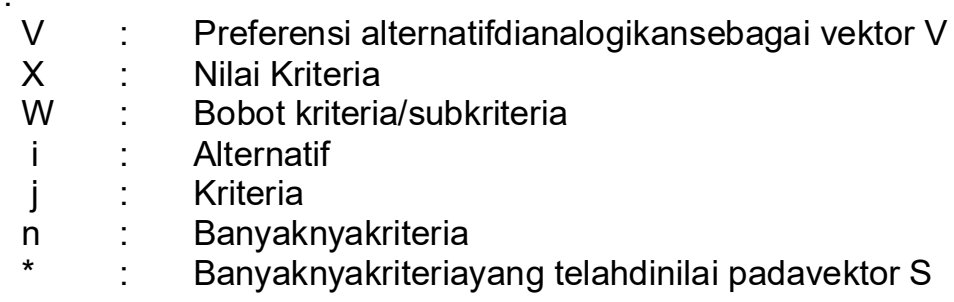




\section{ILKOM Jurnal Ilmiah Volume 9 Nomor 3 Desember 2017}

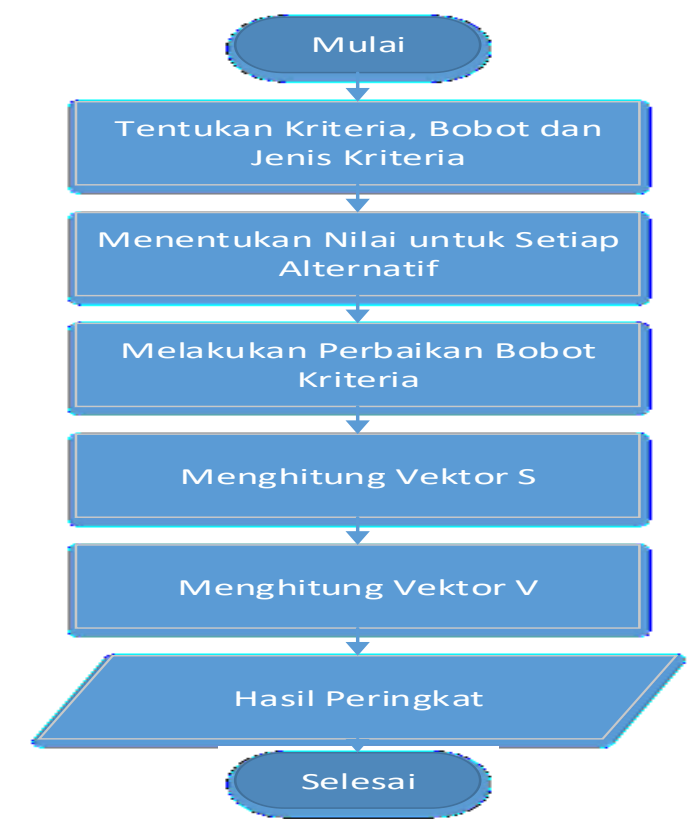

Gambar 1.Tahapan Perhitungan Metode WP

\section{Hasil dan Pembahasan}

Penelitian ini menghasilkan sebuah sistem dekstop, berikut salah satu tampilan form dari aplikasi sistem pendukung keputusan yang sudah dibuat :

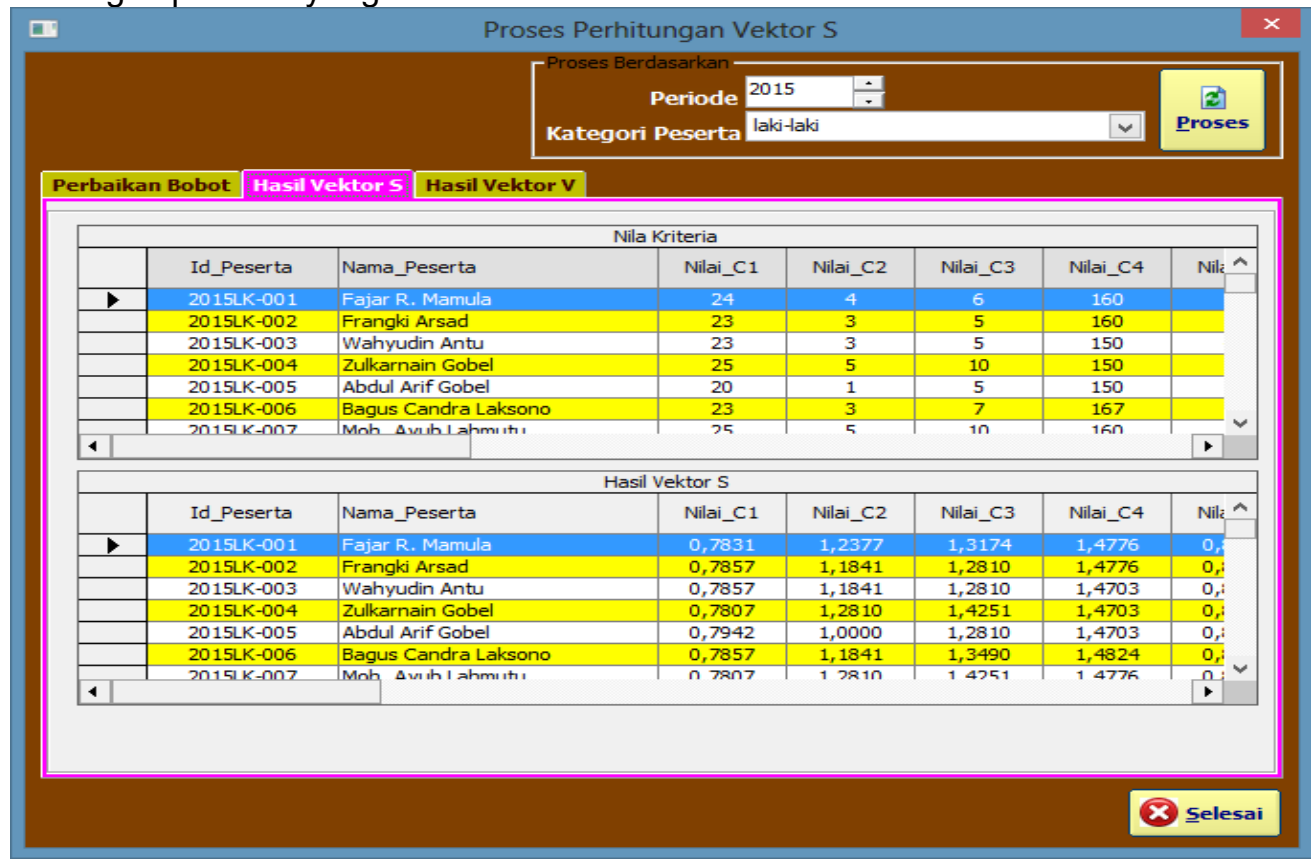

Gambar 2. Form Perhitungan Metode WP

Form ini digunakan untuk melakukan proses perhitungan metode WP, dimana sebelum mengklik tombol proses, sebelumnya ditentukan dulu periode dan jenis kategori peserta yang akan ditentukan, berikutnya hasilnya akan ditampilkan dalam tiga bagian, bagian pertama hasil perhitungan perbaikan bobot dari setiap kriteria, kedua ditampilkan hasil perhitungan Vektor $S$ dan ketiga ditampilkan hasil perhitungan Vektor $V$ atau hasil peringkat peserta yang sudah diurutkan dari alternatif terbaik sampai dengan yang terendah. Apabila diinginkan memilih 2 peserta setiap kategori, maka sistem merekomendasikan peserta yang berada pada ururtan 1 dan 2 sebagai alternatif terbaik sebagai peserta Kapal Pemuda Nusantara. 
Berdasarkan hasil penelitian di atas, berikut ini diuraikan cara penerapan metode WP dalam penentuan pengambilan keputusan.

Tahap 1. Penentuan Kriteria, bobot dan Jenis Kriteria

Tabel 1. Kriteria Pemilihan Peserta Kapal Pemuda Nusantara

\begin{tabular}{|c|l|c|l|}
\hline Kode & \multicolumn{1}{|c|}{ Nama Kriteria } & Bobot & \multicolumn{1}{|c|}{ Jenis Kriteria } \\
\hline C1 & Usia & 2 & Cost \\
\hline C2 & Pendidikan Terakhir & 4 & Benefit \\
\hline C3 & $\begin{array}{l}\text { Jumlah Prestasi Dibidang Organisasi } \\
\text { Kependudukan }\end{array}$ & 4 & Benefit \\
\hline C4 & Tinggi Badan & 2 & Benefit \\
\hline C5 & Berat Badan & 1 & Cost \\
\hline C6 & Daya Tahan Renang & 3 & Benefit \\
\hline C7 & $\begin{array}{l}\text { Jumlah Kesenian Dan Budaya Daerah } \\
\text { Yang Dikuasai }\end{array}$ & 5 & Benefit \\
\hline C8 & $\begin{array}{l}\text { Nilai Proposal Tentang Potensi } \\
\text { Kebaharian Daerah Asal Peserta }\end{array}$ & 5 & Benefit \\
\hline
\end{tabular}

Tahap 2. Memasukkan nilai alternatif untuk setiap Kriteria (sampel 5 peserta)

Tabel 2. Nilai Alternatif Pada Setiap Kriteria

\begin{tabular}{|l|c|c|c|c|c|c|c|c|}
\hline \multirow{2}{*}{ Alternatif } & \multicolumn{10}{|c|}{ Kriteria } \\
\cline { 2 - 9 } & C1 & C2 & C3 & C4 & C5 & C6 & C7 & C8 \\
\hline Peserta 1 & 24 & 4 & 6 & 160 & 50 & 10 & 5 & 69 \\
\hline Peserta 2 & 23 & 3 & 5 & 160 & 50 & 11 & 5 & 74 \\
\hline Peserta 3 & 23 & 3 & 5 & 150 & 40 & 15 & 5 & 79 \\
\hline Peserta 4 & 25 & 5 & 10 & 150 & 52 & 12 & 4 & 67 \\
\hline Peserta 5 & 20 & 1 & 5 & 150 & 42 & 10 & 5 & 65 \\
\hline
\end{tabular}

Tahap 3. Perbaikan Bobot Kriteria

Total bobot $\sum w_{j}=1$, sehingga perlu diadakan perbaikan bobot dengan cara :

$$
W_{1}=\frac{W_{j}=\frac{W_{j}}{\sum W_{j}}(3)}{2+4+4+2+1+3+5+5}=\frac{2}{26}=0,08
$$

Lakukan cara sama untuk mencari $\mathrm{W}_{2}$ sampai dengan $\mathrm{W}_{8}$, sehingga didapat hasil sebagai berikut :

Tabel 3. Perbaikan Bobot Setiap Kriteria

\begin{tabular}{|c|c|c|c|c|c|c|c|c|c|}
\hline Kriteria & C1 & C2 & C3 & C4 & C5 & C6 & C7 & C8 & Jumlah \\
\hline Bobot & 2 & 4 & 4 & 2 & 1 & 3 & 5 & 5 & $\mathbf{2 6}$ \\
\hline $\begin{array}{c}\text { Perbaikan } \\
\text { Bobot }\end{array}$ & 0.08 & 0.15 & 0.15 & 0.08 & 0.04 & 0.12 & 0.19 & 0.19 & $\mathbf{1}$ \\
\hline
\end{tabular}

Tahap 4. Menghitung vektor $S$ berdasarkan persamaan 1 sebagai berikut : 


$$
\begin{aligned}
& S_{1}=\left(24^{-0,08}\right)\left(4^{0,15}\right)\left(6^{0,15}\right)\left(160^{0,08}\right)\left(50^{-0,04}\right)\left(10^{0,12}\right)\left(5^{0,19}\right)\left(69^{0,19}\right)=6,5133 \\
& S_{2}=\left(23^{-0,08}\right)\left(3^{0,15}\right)\left(5^{0,15}\right)\left(160^{0,08}\right)\left(50^{-0,04}\right)\left(11^{0,12}\right)\left(5^{0,19}\right)\left(74^{0,19}\right)=6,2293
\end{aligned}
$$

Lakukan cara sama untuk mencari $S_{3}$ sampai dengan $S_{5}$, sehingga didapat hasil sebagai berikut :

Tabel 4. Perhitungan Vektor S

\begin{tabular}{|c|c|c|c|c|c|c|c|c|c|}
\hline \multirow{2}{*}{ Alternatif } & \multicolumn{7}{|c|}{ Kriteria } & \multirow{2}{*}{ Hasil } \\
\cline { 2 - 10 } & $\mathbf{C 1}$ & $\mathbf{C 2}$ & $\mathbf{C 3}$ & $\mathbf{C 4}$ & $\mathbf{C 5}$ & $\mathbf{C 6}$ & $\mathbf{C 7}$ & $\mathbf{C 8}$ & \\
\hline $\mathrm{S}_{1}$ & 0.78 & 1.24 & 1.32 & 1.48 & 0.86 & 1.30 & 1.36 & 2.26 & 6.5133 \\
\hline $\mathrm{S}_{2}$ & 0.79 & 1.18 & 1.28 & 1.48 & 0.86 & 1.32 & 1.36 & 2.29 & 6.2293 \\
\hline $\mathrm{S}_{3}$ & 0.79 & 1.18 & 1.28 & 1.47 & 0.87 & 1.37 & 1.36 & 2.32 & 6.5616 \\
\hline $\mathrm{S}_{4}$ & 0.78 & 1.28 & 1.43 & 1.47 & 0.86 & 1.33 & 1.31 & 2.24 & 7.0260 \\
\hline $\mathrm{S}_{5}$ & 0.79 & 1.00 & 1.28 & 1.47 & 0.87 & 1.30 & 1.36 & 2.23 & 5.1387 \\
\hline
\end{tabular}

Tahap 5. MenghitungVektor $\mathrm{V}$ yang akan digunakan untuk perankingan dapat dihitung berdasarkan persamaan 2 sebagai berikut :

$$
\begin{aligned}
& V_{1}=\frac{6,5133}{6,5133+6,2293+6,5616+7,0260+5,1387}=0,20698 \\
& V_{2}=\frac{6,2293}{6,5133+6,2293+6,5616+7,0260+5,1387}=0,19795
\end{aligned}
$$

Lakukan cara yang sama untuk $V_{3}$ sampai dengan $V_{5}$, sehingga didapat hasil sebagai berikut :

Tabel 5. Perhitungan Vektor $\mathrm{V}$

\begin{tabular}{|c|c|c|}
\hline Alternatif & Hasil & Peringkat \\
\hline V1 & 0.20698 & 3 \\
\hline V2 & 0.19795 & 4 \\
\hline V3 & 0.20851 & 2 \\
\hline V4 & 0.22327 & 1 \\
\hline V5 & 0.16329 & 5 \\
\hline
\end{tabular}

Tabel 6. Alternatif Terbaik Kategori Laki-Laki

\begin{tabular}{|c|c|c|}
\hline Alternatif & Hasil & Peringkat \\
\hline Peserta 4 & 0.22327 & 1 \\
\hline Peserta 3 & 0.20851 & 2 \\
\hline Peserta 1 & 0.20698 & 3 \\
\hline Peserta 2 & 0.19795 & 4 \\
\hline Peserta 5 & 0.16329 & 5 \\
\hline
\end{tabular}

Berdasarkan tabel 6 di atas dapat dilihat hasil perangkingan alternatif mulai dari alternatif yang memiliki nilai terbesar sampai dengan alternatif yang memiliki nilai terkecil. Pemilihan peserta Kapal Pemuda Nusantara untuk kategori Laki-Laki berdasarkan hasil perhitungan, direkomendasikan untuk memilih Peserta 4 dengan nilai 0,22327 dan Peserta 3 dengan nilai 0,20851sebagai alternatif terbaik serta peserta cadangan Peserta 1 dengan nilai 0,20698.

Berikut penilaian alternatif untuk peserta kategori Perempuan, kemudian dilakukan perhitungan metode WP seperti tahapan di atas sehingga didapat hasil alternatif terbaik. 
ILKOM Jurnal Ilmiah Volume 9 Nomor 3 Desember 2017

Tabel 7. Nilai Alternatif Kategori Perempuan

\begin{tabular}{|c|c|c|c|c|c|c|c|c|}
\hline \multirow{2}{*}{ Alternatif } & \multicolumn{7}{|c|}{ Kriteria } \\
\cline { 2 - 10 } & C1 & C2 & C3 & C4 & C5 & C6 & C7 & C8 \\
\hline Peserta 1 & 20 & 3 & 4 & 145 & 45 & 15 & 3 & 75 \\
\hline Peserta 2 & 20 & 4 & 5 & 148 & 46 & 11 & 4 & 70 \\
\hline Peserta 3 & 23 & 3 & 5 & 150 & 48 & 13 & 5 & 79 \\
\hline Peserta 4 & 18 & 2 & 7 & 150 & 52 & 12 & 4 & 74 \\
\hline Peserta 5 & 20 & 2 & 5 & 146 & 42 & 12 & 2 & 78 \\
\hline
\end{tabular}

Tabel 8. Alternatif Terbaik Kategori Perempuan

\begin{tabular}{|c|c|c|}
\hline Alternatif & Hasil & Peringkat \\
\hline Peserta 3 & 0.21771 & 1 \\
\hline Peserta 2 & 0.21131 & 2 \\
\hline Peserta 4 & 0.20513 & 3 \\
\hline Peserta 1 & 0.19398 & 4 \\
\hline Peserta 5 & 0.17187 & 5 \\
\hline
\end{tabular}

Pemilihan peserta Kapal Pemuda Nusantara untuk kategori Perempuan berdasarkan hasil perhitungan, direkomendasikan untuk memilih Peserta 3 dengan nilai 0,21771 dan Peserta 2 dengan nilai 0,21131 sebagai alternatif terbaikserta peserta cadangan adalah Peserta 4 dengan nilai 0,20513.

\section{Kesimpulan dan Saran}

Berdasarkan hasil penelitian di atas dapat ditarik kesimpulan sebagai berikut:

1. Metode Weighted Product (WP)bisa digunakan untuk memilih alternatif atau peserta terbaik dalam pemilihan peserta Kapal Pemuda Nusantara untuk kategori Laki-Laki dengan nilai tertinggi 0,22327 dan untuk kategori Perempuan dengan nilai tertinggi 0,21771

2. AplikasiSistemPendukung Keputusan yang sudah dibuat bisa memberikan hasil yang lebih obyektif.

3. Disarankan kepada peneliti berikutnya bahwa penelitian ini dapat diteliti kembali dengan menggunakan metode MADM yang lainnya atau gabungan dua metode mislanya metode AHP dan WP, agar hasil bisa dibandingkan mana yang lebih baik.

\section{Daftar Pustaka}

[1] Kementerian Pemuda dan Olahraga RI. 2015. Panduan Seleksi Peserta Kapal Pemuda Nusantara 2015. Jakarta

[2] Kusumadewi, dkk.,2006, Fuzzy Multi-Atribute Decision Making (Fuzzy MADM), Yogyakarta: Graha IImu

[3] Lestari S. 2013. Penerapan Metode Weighted Product Model untuk Seleksi Calon Karyawan, Jurnal Sistem Informasi Vol. 5, No. 1 ISSN Print 2085-1588, ISSN Online 2355-4614

[4] Arsyad M. 2016. Sistem Pendukung Keputusan untuk Seleksi Calon Ketua Badan Ekskeutif Mahasiswa (BEM) STMIK Banjarbaru dengan metode Weighted Product (WP). Jurnal Bianglala Informatika Vol 4 No. 1. ISSN Print 2338-8145, ISSN Online 2338-9761

[5] Niswatin, R.K. 2016. Sistem Seleksi Penerimaan Mahasiswa Baru menggunakan metode Weighted Product (WP). Seminar Nasional Teknologi Informasi dan Multemedia. ISSN 23023805

[6] Turban, dkk, 2005, Decision Support Systems and Intelligent Systems, Yokyakarta : Andi

[7] Kusrini, 2007, Konsep dan Aplikasi Sistem Pendukung keputusan, Yokyakarta: Andi. 